\title{
Historical Reality, Fictional Narrative
}

China in the Frame of Gao Xingjian's Theatre

\section{Quah Sy Ren}

\section{(2) OpenEdition}

\section{Journals}

Édition électronique

URL : http://journals.openedition.org/chinaperspectives/5267

DOI : 10.4000/chinaperspectives.5267

ISSN : 1996-4617

Éditeur

Centre d'étude français sur la Chine contemporaine

Édition imprimée

Date de publication : 1 juin 2010

ISSN : 2070-3449

\section{Référence électronique}

Quah Sy Ren, « Historical Reality, Fictional Narrative », China Perspectives [En ligne], 2010/2 | 2010, mis en ligne le 01 juin 2013, consulté le 28 octobre 2019. URL : http://journals.openedition.org/ chinaperspectives/5267; DOI : 10.4000/chinaperspectives.5267 


\title{
Historical Reality, Fictional
}

\section{Narrative}

\author{
China in the Frame of Gao Xingjian's Theatre
}

\author{
QUAH SY REN
}

With reference to Erving Goffman's notion of "frame analysis" and Colin Counsell's "framing signifiers," this article explores how Gao Xingjian, the first Chinese-language Nobel laureate for literature, has represented the reality of contemporary China in his dramatic works. Focusing on two scenes in one of Gao's early plays, The Other Shore, it aims to illustrate the way Gao uses the narrative technique of framing to inversely (un/re)frame the notions of China and Chineseness.

\section{China as frame}

I t is widely acknowledged that Gao Xingjian was the first Chinese writer to win the Nobel Prize for Literature.

However, such a statement apparently demands further scrutiny. If the qualifying term "Chinese" refers to a geo-political entity, then the statement is not exactly true. ${ }^{(1)} \mathrm{Al}-$ though Gao was born in China and was once a citizen of the People's Republic of China and a member of the Chinese Communist Party, he left China for good in 1987 and had already become a naturalised French citizen at the time he was awarded the Nobel Prize in 2000. That being the case, can Gao still be considered a "Chinese" writer? And is this a crucial question to be raised? This issue, especially to many Chinese (with respect to both nationality and ethnicity, and used with awareness of the complexity of the concept) in China and overseas, is apparently a vital one. However, it has also to be recognised that the notion of Chinese - and Chineseness - is complex and multifaceted, referring not only to nationality but also to language, culture, history, experience, memory, and more. This article does not intend to discuss the complexity of Chinese and Chineseness, but aims to illustrate how Gao as a "Chinese" writer uses the narrative technique of framing to inversely (un/re)frame these notions in his dramatic works, with an emphasis on his earlier plays, especially a close reading of two scenes from The Other Shore.

Two years prior to Gao's award, Liu Zaifu wrote a long essay entitled "A Hundred Years of the Nobel Prize for Literature and the Absence of Writers from China." In this essay, Liu raises a question: "The works of the members of this celebrated family [of Nobel Literature Prize winners] essentially constitute a significant framework for the understanding of world literature in the twentieth century, but writers from China have always been wandering at the door of this family and outside this framework, being denied a chance to participate in this festive carnival of literature. Why is that so?" (2) Reading this argument easily calls to mind C.T. Hsia's famous notion of the "obsession with China." (3) Indeed, this psychological self-doubt is especially exemplified in the desire for a Nobel Prize for Literature. Hence one may ask whether Gao's being awarded the Nobel Prize provides a satisfactory and happy answer to Liu's question. Apparently, the case is not so straightforward. After the award to Gao was announced in October 2000, it did not bring such queries to rest but stirred up more agitation and controversy. ${ }^{(4)}$ To Liu, however, Gao's award apparently provided a positive answer to his question. Immediately after the award announcement, Liu observed, "[Gao's] experience is in China and he writes about China, but he is not confined to China... He writes with the Chi-

1. In the English version of the Swedish Academy's News Release (12 October 2000), Gao Xingjian was described as a "Chinese writer," claiming that his work "has opened new paths for the Chinese novel and drama." In the Chinese version, the term used to describe Gao was less ambiguous: "Zhongwen zuojia," literally translated into "Chinese-language writer." See http://nobelprize.org/nobel_prizes/literature/laureates/2000/ press.html.

2. Liu Zaifu, "Bainian Nuobei'er wenxuejiang he Zhongguo zuojia de quexi" (A hundred years of Nobel Prize for Literature and the absence of writers from China), in Liu, Gao Xingjian Iun (On Gao Xingjian), Taipei, Lianjing, 2004, p. 237. First published in Lianhe wenxue (Unitas), January 1999.

3. C.T. Hsia, "Obsession with China: The Moral Burden of Modern Chinese Literature," in Hsia, A History of Modern Chinese Fiction, 2nd edition, New Haven, Yale University Press, 1971, pp. 533-609.

4. For the response to Gao's award and related controversies, see Julia Lovell, The Politics of Cultural Capital: China's Quest for a Nobel Prize in Literature, Honolulu, University of Hawaii Press, 2006. 
nese language, our mother tongue, and his writing is full of the gist of Chinese Zen and the flavour of the mother tongue. As such, his success is the success of our mother tongue." (5) In his earlier essay, Liu's focus on "China" is obviously a notion of nationality. He has even detailed a list of Nobel Prize winners and their nationalities since the first conferment in 1901, highlighting the number of winners according to their nationalities. ${ }^{(6)}$ Liu's proposition is understandable. The nationality of the winner had never been such a contentious issue before Gao was named one. Interestingly, although Liu uses the term "China" several times in his latter essay, he does confine the concept of "China" within the boundary of nationality, but suggested that "China" was more related to Gao's personal and cultural experience, as well as an image represented in his writing, particularly in his novels Lingshan (Soul mountain) and Yige ren de shengjing (One man's Bible).

In their reading of Gao's works, critics have often perceived "China" as a significant symbol, be it a simplistic reference to nationality or a more general one to Gao's personal and cultural experience. In so doing, they clearly use "China" - in linguistic, cultural and/or political terms - as an important reference point. In other words, China is a frame in which Gao's works, as well as Gao as a person, are being interpreted and assessed. It is a fact that before the late 1980s, Gao's life and work were closely, if not exclusively, related to China - as defined in geographical, cultural, social, and political terms. To discuss Gao's works in this specific context is understandably legitimate and necessary. Taken out of this context of "China," a reading of Gao - even his reflections on and dialogue with European theatre and intellectual history - may well be seen as an incomplete assessment. However, when "China" is used as a framework to understand Gao and his works, it will inevitably become a restrictive and even repressive force, leading to the exclusion and neglect of other aspects of his works. As a writer, Gao's most distinguished characteristic is his refusal and resistance to being framed, especially within the frame of China as a geo-political concept. Gao's stance implies that he has often adopted a critical approach towards his experience (particularly of politically motivated oppression) in relation to China and the authorities in China, which is clearly demonstrated in his writings.

Through the abundant research materials published in recent years, readers are also familiar with Gao's experience in China and his views towards China. ${ }^{(7)}$ Two incidents in particular, namely, the Cultural Revolution from 1966 to 1976 and the Tiananmen Incident in 1989, clearly emerge as the most disturbing to the writer:
At the beginning of the Cultural Revolution, I was involved in rebel action as a leader of a Red Guard group. However, I soon became disgusted with the power struggles within the organization and tried very hard to get away from it. After the Tiananmen Incident, I renounced my membership in the Chinese Communist Party and decided never to join any political organization or participate in any political activities. ${ }^{(8)}$

The ten-year Cultural Revolution was certainly the most distressing experience for $\mathrm{Gao}$, who had just graduated from the Beijing Institute of Foreign Languages and was entering his most productive and creative young adulthood. Memories of his personal experience in the Cultural Revolution form a large part of his novel One Man's Bible. The Tiananmen Incident, although it took place after he had already gone into exile in Paris, was the last straw for $\mathrm{Gao}$, as it epitomised the brutal oppression of the Chinese Communist Party. Soon after, Gao wrote the play Taowang (Fugitives), loosely based on the Tiananmen Incident, and also publicly announced that he would relinquish his membership in the Chinese Communist Party. Both incidents were again highlighted in Gao's speech when he received the Nobel Prize in December 2000 at the Swedish Academy. ${ }^{(9)}$ It is therefore understandable that these two major political incidents in the recent history of the People's Republic have been repeatedly represented, implicitly or explicitly, in Gao's novels and plays.

As a writer as well as an intellectual, Gao has not only in many instances vividly represented such personal and collective experiences in his writings, but has also displayed his profound reflection on related issues. One of the key issues he has frequently discussed is the relationship between the individual and the collective, in which the former is perceived as suppressed by the latter. One of his strongest and most representative critiques on this topic is expressed in "The Voice of the Individual," a lecture Gao delivered at a

5. Liu Zaifu, "Xin shiji Ruidian Wenxueyuan de diyi pian jiezuo" (The first good news of the new century from the Swedish Academy), in Liu, Gao Xingjian lun, p. 204. First published in Mingbao yuekan, November 2000.

6. Liu Zaifu, "Bainian Nuobei'er wenxuejiang he Zhongguo zuojia de quexi," pp. 248-254.

7. A detailed description of Gao's personal experience before he was awarded the Nobel Prize can be found in Sy Ren Quah, Gao Xingjian and Transcultural Chinese Theater, Honolulu, University of Hawaii Press, 2004, pp. 4-13.

8. Gao Xingjian, "Lun wenxue xiezuo" (On literary writing), in Gao, Meiyou zhuyi (No-ism), Hong Kong, Tiandi tushu, 1996, p. 55.

9. Gao Xingjian, "The Case for Literature," in Gao, The Case for Literature, translated by Mabel Lee, Sydney, Fourth Estate, 2006, pp. 33-34. 
conference at Stockholm University in 1993. In the lecture, he asserts that

it is precisely in the uncompromising independence of the individual that the creative spirit lies. When the intellectual confronts society as an individual, his existence is more real. If the self of the intellectual is dissolved in the collective big self, or what is known as "we," the individual self no longer exists. ${ }^{(10)}$

Gao's position as an independent, critical intellectual is in many ways similar to that of many other modern writers and thinkers of the twentieth century. In his seminal lecture series Representations of the Intellectual, Edward W. Said discusses at length how modern intellectuals negotiate and maintain their independence in the face of increasingly overwhelming state hegemony. Among them, the case of the German thinker Theodor Adorno is highly relevant to the present discussion of Gao. In Said's view,

Paradoxical, ironic, mercilessly critical: Adorno was the quintessential intellectual, hating all systems, whether on our side or theirs, with equal distaste. For him life was at its most false in the aggregate-the whole is always the untrue, he once said-and this, he continued, placed an even greater premium on subjectivity, on the individual's consciousness, on what could not be regimented in the totally administered society. (original emphasis) ${ }^{(11)}$

Comparing Said's assessment of Adorno with the previous quotation from Gao's lecture, one can clearly identify a parallel between the two, that is, the assertion that one of the most important characteristics of a modern intellectual is his rejection of and resistance to the idea of the collective. The intellectual, in Said's view, has often been sceptical of claims in the name of a collective, especially the claim to represent the individuals encompassed in this notion of the collective. With regard to Gao's experience, this collective obviously refers to the dominant political ideology and practices. It is not my intention to discuss this notion of the collective, however. In the sections that follow, I would like to propose taking a closer look at the strategies adopted by Gao in his resistance to the oppression from the collective. What Said mentioned about Adorno, the "[p]aradoxical, ironic, mercilessly critical" characteristics of Adorno, as well as the fictionality of the notion of the collective, are some arguably useful approaches to Gao's works.

\section{Framing, the fictional frame and the framed reality}

A text has to be placed within a certain framework to be understood and interpreted. The meaning of the text is generated with regards to the rules and premises of the framework in which it is situated. In this sense, the meaning of Gao and his works will be very different if they are placed within the framework of "China" or that of "Modernism." (12) When a certain framework is adopted for the reading of a text, readers will be directed to use a perspective permitted by the framework to understand the text. The meaning of the text will therefore be limited by the boundary of that framework. In his book entitled Frame Analysis: An Essay on the Organization of Experience, the sociologist Erving Goffman mentioned that "frameworks are not merely a matter of mind but correspond in some sense to the way in which an aspect of the activity itself is organized," and the participants of an activity fit their actions to the understanding of that activity and "find that the ongoing world supports this fitting." (13) These organisational premises, which Goffman termed "the frame of the activity," are the conceptual structure in which social practices are recognised and understood, as well as the reference of an individual's social actions and his/her involvement in an organisational formation.

When Colin Counsell discusses the signs and meanings of theatre performances, he borrows the concept of "framing" from sociological studies, proposing the notion of "framing signifiers." (14) A performance, Counsell argues, is an event isolated from the everyday sphere and thus a "bearer of symbolic meaning" demanding an exercise of decoding:

Being conceptually distanced from the audience, [the abstract register of theatre] functions on a symbolic level. It deals with abstractions - not the tangible and

10. Gao Xingjian, "The Voice of the Intellectual," in Gao, The Case for Literature, p. 133.

11. Edward W. Said, Representations of the Intellectual, New York, Vintage Books, 1996, p. 55.

12. For example, while Mabel Lee discusses Gao's novels as part of the tradition of Chinese intellectual history, some writers compare Gao's The Bus Stop with the Irish playwright Samuel Beckett's Waiting for Godot. For the former, see Mabel Lee, "Gao Xingjian's Fiction in the Context of Chinese Intellectual and Literary History," Literature and Aesthetics: The Journal of the Sydney Society for Literature and Aesthetics 16.1 (June 2006), pp. 7-20. For the latter, see Kwok-Kan Tam, "Drama of Paradox: Waiting as Form and Motif in The Bus-Stop and Waiting for Godot," in Tam (ed.), Soul of Chaos: Critical Perspectives on Gao Xingjian, Hong Kong, Chinese University Press, 2001, pp. 43-66; and Quah, Gao Xingjian and Transcultural Chinese Theater.

13. Erving Goffman, Frame Analysis: An Essay on the Organization of Experience, Boston, Northeastern University Press, 1986, p. 247.

14. Colin Counsell, Signs of Performance: An Introduction to Twentieth-Century Theatre London and New York, Routledge, 1996, pp. 18-19. 
equivocal social world we experience, but a world already quantified, categorised, by the discourse the locus encodes. Thus it construes reality in terms of that discourse's symbolic entities... It is this very quality of symbolic transposition that enables it to be illusionistic. $^{(15)}$

In this respect, when an incident is taken out of its normal everyday context and presented in a theatrical space, the theatre - with all its associated signifying conventions such as the building, surrounding environment, social setting, performance time, etc. - will act as the framing signifiers of that particular incident. As such, the incident is perceived and understood within this newly adopted framework, and hence new meanings are generated. Counsell also mentions a creative strategy that some modern artists have employed, that is to situate an object in a context that is usually unrelated to that object (not necessarily a theatrical space), and which forces the viewers "to find symbolic meaning in objects which were categorically non-symbolic." Such a strategy employed by artists in leading audiences to abandon the original meaning and to create new meaning of an object is, in Counsell's words, "framing the everyday." (16)

To disassociate and transfer an object from its original context is a strategy commonly employed by modernist artists and writers in order to generate new meaning out of an object that has become too familiar to the audience and thus appears to be meaningless. The significance of such a strategy is that the practice usually makes use of a framework that surprises the audience and guides them to view the object in a new light. When the meaning of an old object has changed with the presence of new framing signifiers, members of the audience are forced to rethink the connection between the object and its original context. In this regard, the strategy of (re)framing the everyday is a powerful weapon of the modernists to challenge reality and the status quo. In the course of rethinking the ordinary and normal, the mainstream ideology signified by the normalisation of the understanding of reality is subverted, and in the process existing power relations are questioned. In contrast, realists attempt to represent everyday life and people in a context in which they appear appropriate and normal. In their view, it is only when life and people are situated in an appropriate and realistic context that their real meanings are exemplified, and that the audience is able to understand them from an effective perspective. Framework is of equal importance to realists and modernists, but in a realist framing, the production of meaning will inevitably be dictated by realist ideology.
Juedui xinhao (Alarm signal), staged in 1982, exemplifies such an ideological framing, largely within Chinese realist narrative conventions. Realism has been the dominant form of theatrical representation in China since modern spoken drama emerged in the early twentieth century, and all the more so in the socio-political context following the establishment of the People's Republic of China. Realist theatre is perceived as mimicry of reality and hence as serving the objective of educating and enlightening the people, especially with regard to the socialist regime. Gao joined the ranks of professional playwrights in the Beijing People's Art Theatre, the country's most prominent and celebrated theatre company and a traditional stronghold of realist theatre. It was in this context that $\mathrm{Gao}$ produced his first play with cautious attempts to challenge realist tradition and ideology.

Staged in a rehearsal studio of the Beijing People's Art Theatre, Alarm Signal depicts the story of a train robbery, an incident that the play suggests is primarily caused by the prevailing problem of unemployment, particularly among the generation that entered the workforce soon after the launch of Deng Xiaoping's marketisation policy. ${ }^{(17)}$ Although there are instances of non-realistic exposition of the characters' psychological journey, the plot of Alarm Signal generally resonates with that of Chinese realist drama of that era, which on the one hand details the personal/social journey of the protagonists, and on the other, indisputably proposes a final resolution to the pre-dénouement crises. The staging of the play used exposition through internal monologues and dreamlike theatrical effects, which were perceived as innovative at the time compared to conventional realist representation. However, the main dramatic narrative is realistic and linear, focusing on the "why" and "how" of the incident, and ultimately providing a direct and didactic answer, i.e., that people should have an optimistic outlook under the leadership of the Chinese Communist Party, regardless of temporary setbacks perceived in the process. It is apparent that Alarm Signal's characterisation and resolution in a realist style, a convention generally familiar to the audience, leads them to view and understand the social issues represented in the play with close reference to social and economic development in the early 1980s. Alarm Signal was Gao's first play to be staged, and also his first and only play to receive

15. Colin Counsell, Signs of Performance, p. 19.

16. Colin Counsell, Signs of Performance, pp. 211-212.

17. Alarm Signal was first staged in a converted studio-theatre of the Beijing People's Art Theatre in November 1982. The script was first published in Shiyue, No.5 (1982) and later collected in Gao Xingjian, Juedui xinhao (Alarm signal), Taipei, Lianhe wenxue chubanshe, 2001. 
overwhelming positive responses across the country. ${ }^{(18)}$ The play, although celebrated as the first avant-garde production of contemporary China, shows a general conformance to official realist ideology in terms of its representation of reality. In addition, the way social issues are represented and resolved in the play also corresponds to the expectation of the general public. In short, the huge success of the staging of Alarm Signal signifies that the play did not effectively go beyond the usual frame of understanding those social issues.

Chezhan (The bus stop) is Gao's second play presented by the Beijing's People Art Theatre. Written before Alarm Signal and staged in 1983, The Bus Stop displays a totally different framing effect, and hence met with a different fate. ${ }^{(19)}$ The play depicts seven characters of various social backgrounds waiting at a suburb bus stop for a bus to bring them to the city. These characters are apparently chosen to represent Chinese people from various walks of life, and are perceived by critics as those who hope to share in the fruits of economic reform. At first, buses arrive but do not stop to pick them up. Later on, no bus appears at all. Alarm Signal presents a linear narrative that runs through the entire play in a realist style, and The Bus Stop starts with a not dissimilar realist representation of the situation of the characters waiting for a bus. Halfway through the play, however, the dramatic situation takes a surreal and absurd turn when the characters start to realise that they have in fact been waiting at the bus stop for more than ten years, and that they are unable to escape from the trap of the space demarcated by the bus stop. The expansion of dramatic time and compression of dramatic space, occurring suddenly and simultaneously, suggest that the narrative of The Bus Stop has surmounted the limitations of physical time and space. With this change in narrative style, the characters and their stories, which first appear to be realistic, are now framed in an absurdist situation that is entirely fictitious and breaks all rules of realist convention. This requires audiences and readers to take a perspective different from that of their everyday life and comprehend the issues within the fictional framework set up by the author. With such a frame in place, things that are otherwise ordinary and familiar demand a new way of understanding. The difference between Gao's two early plays is that while Alarm Signal presents some elements of nonrealist representation within a largely realist framework, The Bus Stop employs a fictional framework to first accommodate and later transform realistic characters and incidents. In contrast to the approach in Alarm Signal, which generally aligns with the official stance of mobilising large-scale participation in economic reform and obscuring the problems that have emerged in that process, the realist-turn-surrealist narrative in The Bus Stop presents the irony of the situation and hence is perceived as a critique in alternative voice. It is hardly surprising that the performance of The Bus Stop was quickly called to an abrupt halt, and Gao was obliged to flee from Beijing immediately after the Anti-Spiritual Pollution Campaign was launched. ${ }^{(20)}$

Goffman's discussion of his frame theory uses many examples of theatre and performance to illustrate how framing works. ${ }^{(21)}$ Regardless of genre, period or region, a performance is usually carried out in a specific frame, primarily in the sense of its physicality. The concept of frame I am going to discuss here is primarily the mode of narrative as a technique of structuring, representing, and role-playing. On the first level, how the story in a performance is being told and how the audience is to understand that it is told is determined by the narrative frame employed by a playwright. This framing process takes place not in the theatre but in the written script. The second and third levels of framing, however, take place in the theatrical space. It is the task of the director to turn the words on the page into a physically visible performance with his second-degree creation, which takes the play to the second level of framing. At the last stage, the fabricated story is told and the fictional characters are represented by real-life performers, thus bringing the performance to the third level of framing. These frames are consciously created and presented by all the above parties in the process of creating a performance. In a naturalist/realist style of performance, however, some levels of framing are deliberately erased. When a Stanislavskian director requires the performance to be performer-centred, he wants the audience to believe that what is represented on stage is real. In so doing, the first (playwright) and second (director) levels of framing become invisible in the physical theatrical space, and the performer has to discard the identity of his/her real self and totally immerse himself or herself in the character, assuming that the fictional world of the theatre is the real

18. Gao Xingjian, "Wilted Chrysanthemums," in Gao, The Case for Literature, p. 143.

19. The Bus Stop was first staged in July 1983. The script first appeared in Shiyue, no. 3 (1983) and was later collected in Gao Xingjian, Chezhan (The bus stop), Taipei, Lianhe wenxue chubanshe, 2001. The Bus Stop was the first play Gao wrote after joining the Beijing People's Art Theatre as a professional playwright. See Gao, "Wilted Chrysanthemums," p. 141.

20. The Anti-Spiritual Pollution Campaign (1983-1984) was a political campaign launched by some factions in the Chinese Communist Party against the alleged spread of liberal ideas from the West as a result of the reform and opening policy launched in 1978. The Bus Stop`s staging in July 1983 came just as the campaign was about to be launched (September 1983).

21. There is an entire chapter entitled "The Theatrical Frame" in which Goffman discusses how the frame of theatre works in a different way from that of everyday life. See Erving Goffman, Frame Analysis, pp. 123-155. 
world. In the process, the third level of framing signified by the action of performing is also erased. When all three levels are expunged from the performance, the fictionality of theatre is hidden, suggesting that the theatre is a "reflection" of reality. Paradoxically, the audience is asked to believe that what is happening in the theatre is nothing less than real, through the creation of an entire world made up of illusions. When Gao incorporated a perceptibly fictional framework in his play The Bus Stop, and deliberately exposed and performed the fictional aspects of the play to the audience, he clearly wanted his audience to be aware of the fictionality of theatre and to perceive theatre as a place where actors are acting out roles and not one that represents a mimicry of real life. In a Stanislavskian-style performance, the audience is usually required to believe that what they are seeing is real, resulting in emotional and rational investment. In The Bus Stop, however, Gao and director Lin Zhaohua used the exposition of the performance and dramatic framing to clearly differentiate the real from the fictional, thereby compelling the audience to face the oppositional, complicated relations, and even the irresolvable entanglement, of the real and the fictional. In this regard, the fictional frame in Gao's theatre is not merely a novel form, but is fundamentally the main theme of the play, which the audience needs to understand, to accept, and to ponder. The exposition of theatrical fictionality in The Bus Stop is perhaps the key difference between this play and Gao's earlier Alarm Signal, and is also why these two productions were received very differently by the authorities. Alarm Signal, with its positive representation of the official stance, was celebrated as a successful experiment despite its minimal formal innovation, whereas The Bus Stop was sternly perceived as a criticism of the party-state. As discussed earlier, Gao strongly rejects the concept of the collective, and also resists being represented by the collective. At the same time, his rejection of a connection with the geo-political notion of China may be seen as his resistance to his works and himself being understood within the framing of this notion of China. (It should not, however, be assumed that Gao holds an antagonistic view toward China in cultural and linguistic terms. On the contrary, the cultures of China are a fundamental part of his thought and works.) One might ask, what is Gao's strategy as a playwright in representing and resisting China? In the first place, Gao does not resist by avoiding. He has often openly and directly discussed China and Chinese society, culture, and politics, especially in his essays. Secondly, since his first play Alarm Signal, Gao has shown great interest in the fictionality of dramatic framing and has consciously employed the strategy of framing to represent issues related to China. In so doing, Gao has constructed a specific framework for representing and discussing these issues. With this in mind, I will proceed in the following section to discuss how Bi'an (The other shore) represents incidents of the Cultural Revolution, and how Gao uses dramatic framing to reflect on this significant episode in the history of contemporary China.

\section{The Other Shore: History and memory in frame}

The Other Shore is the fourth full-length play written by $\mathrm{Gao}$, and also the last play he wrote before leaving China in 1987. ${ }^{(22)}$ According to Gao, this play was written primarily for the training of actors, as Gao was dissatisfied with the actors at the Beijing People's Art Theatre, who were trained in the Stanislavskian system. ${ }^{(23)}$ He envisioned a new kind of actor that was more well-rounded and flexible in creating roles. However, just one month after the training of actors started in 1986, rehearsals came to an abrupt halt due to the Anti-Bourgeois Liberalisation Campaign. The play has never been staged in China since then. ${ }^{(24)}$

While Gao's earlier plays have plots with a linear narrative, ${ }^{(25)}$ The Other Shore is basically non-linear, with seemingly unrelated episodic scenes following one after another. Some characters, such as Mother and Father, are given a realistic identity, while others are purely abstract, such as the dramatic characters named Shadow and Heart. In terms of the sequence of time and logic in the performance, the relation of one scene with another remains rather ambiguous and at times irrational. Among the many scattered episodic scenes in the play, two are relatively longer and more complete, with comprehensible storylines. Interestingly, these two scenes readily remind the audience of certain wellknown collective experiences related to the Cultural Revolution. These incidents are common and may to some extent be Gao's personal experience, which he has also depicted in his autobiographical novel One Man's Bible. It is apparent that the Cultural Revolution was a major incident in Gao's

22. The Other Shore was first published in Shiyue, №.5 (1985). An English version was translated by Gilbert Fong and collected in Gao Xingjian, The Other Shore: Plays by Gao Xingiian, Hong Kong, The Chinese University Press, 1999. Quotations from The Other Shore in the present discussion are all from this translated text.

23. Gao Xingjian, "Bi'an daoyan houji“ (Director's notes on the production of The Other Shore), in Gao, Meiyou zhuyi, p. 223

24. Gao Xingjian, "Wilted Chrysanthemums," p. 153. The Other Shore was later premiered by the Taiwan Arts Academy in 1990 and staged by the Hong Kong Academy for Performing Arts in 1995. The Hong Kong production was directed by Gao himself.

25. Alarm Signal and the first half of The Bus Stop. 
life, which he has revisited in his writings, both critical and creative. While Gao has profoundly reflected on and bluntly criticised the Cultural Revolution, his creative representation of it has been largely metaphorical rather than realistic. I am not going to discuss how the scenes in The Other Shore represent historical reality, but will focus on how they are structured and positioned within the narrative of the entire play. For the sake of discussion, I will refer to the scenes as "Learning to Speak" and "The Card Game," respectively. ${ }^{(26)}$

The scene "Learning to Speak" begins with a group of people (collectively named the Crowd in the play) feeling totally exhausted, lying down on the ground after they cross a river, reaching a place called "the other shore." Among them, a character named Woman appears and awakens the others. The Crowd seems to have lost their memory and their ability to speak. Woman then starts to patiently teach them to speak by through enunciation, the proper nouns, the technique of expression, the meaning of words and so on. By learning to speak, these people also begin to understand interpersonal relations. After they fully acquire the skills of linguistic expression, a character named Man rises from the Crowd and emerges as a leader among them. Man challenges Woman's role as the teacher by asking her a series of questions:

Have you been hiding in our thoughts, do you appear only when we think of you? Or are you something like a kind of consciousness? Did you guide us to the other shore so that we wouldn't get lost? ${ }^{(27)}$

After this, the Crowd quickly becomes noticeably agitated and restless. They begin to use their newly acquired language skills to mercilessly curse and slander Woman, and "are excited by their own increasingly venomous language." ${ }^{(28)}$ Surrounded by the Crowd, Woman has no way to escape and turns to Man for help. By then, the Crowd has gone out of control; they drag Woman away from Man by force and finally strangle her to death.

The story narrated in this scene is straightforward and obviously an allegorical depiction of the Cultural Revolution. It is not my intention to discuss if such a representation of historical reality is accurate. What is interesting is how this story with vivid reference to an episode of recent history has been juxtaposed with other scenes and how it is situated in the narrative frame of the play. Immediately before the scene "Learning to Speak," there is a scene in which a group of performers use body and verbal language to act out the process of crossing the river to reach the opposite shore. In the script, it is written that the place depicted in the play "cannot be defined or stated precisely," and the location is "from the real world to the nonexistent other shore," ${ }^{(29)}$ suggesting that the temporal and spatial coordinates are fictional and thus reminding the audience that what they see in the theatre should not be taken as a reflection of reality or as reality per se. "The other shore," a Buddhist notion signifying a state of spiritual enlightenment beyond one's physical existence, is from the outset given an ironic twist by this suggestion of its "non-existence." At the beginning of the performance, someone named "Actor Playing with Ropes" comes on stage, leading the ensemble actors in a game using ropes as props. It should be noted that this person does not appear with the identity of a dramatic character but as an actor. With reference to Gao's seminal proposition of the neutral actor, this identity of an actor exists before the person enters the identity of a dramatic character, thus providing him/her with a detached, self-conscious position to observe and take up the role. ${ }^{(30)}$ This leads the audience to witness the act of performing, which is different from the conventional realist theatre that requires the audience to engage in a suspension of disbelief. Led by Actor Playing with Ropes, the ensemble invokes the audience's imagination while making obvious the process of performing. The deliberate exhibition of such a process forces the audience to confront the fictionality of theatrical performance, i.e., that what is going on in the show is unreal and should not be perceived as directly, unconditionally connected with the reality outside this specific space. With this awareness of the fictionality of performance established, the audience is directed to perceive and understand the following scenes within this frame of fictionality. Immediately following this exposition of fictionality is the scene "Learning to Speak." ${ }^{311}$ At the end of this scene, after Woman is killed by the Crowd, the Crowd approaches Man, hoping he will lead their way ahead. Man, however, refuses their plea and in turn asks them:

26. "Learning to Speak," see Gao, The Other Shore, pp. 8-14. "The Card Game," see Gao, The Other Shore, pp. 16-23.

27. Gao Xingjian, The Other shore, p. 10.

28. Ibid., p. 11.

29. Ibid., p. 1.

30. For Gao's discussion of the neutral actor and references to The Other Shore, see Gao Xingjian, "Juzuofa yu zhongxing yanyuan" (The craft of playwriting and the neutral actor), in Gao, Meiyou zhuyi, pp. 253-266. See also Gilbert C.F. Fong, "Introduction," in Gao, The Other Shore, pp. xviii-xxiv, and Quah, Gao Xingjian and Transcultural Chinese Theater, pp. 130-136.

31. The concept of fictionality is used with reference to narrative, while another concept of suppositionality is proposed with regards to the discussion of theatricality. For a more detail discussion of the latter, see Quah, Gao Xingjian and Transcultural Theater, pp. 93-129. 
The card-game scene in Gao Xingjian's play The Other Shore, directed by Tang Shu-wing, Carnegie Mellon University Theatre, 2008.

(c) Courtesy of Carnegie Mellon University School of Drama, Pittsburgh, USA

Follow me where? Where can I lead you? Don't follow me! I don't even know where I want to go myself. $^{(32)}$

Leaving the Crowd, Man enters a different temporal-spatial dimension, meeting his mother, who passed away a long time ago, and a girl on whom he had a secret crush during his younger days. Man's dialogue with his mother is very brief and emotionless, without much detail. This short dialogue apparently functions as a transition: after bringing out the memory of Man, the next scene is set in the context of a distant past. In contrast to the brief encounter with his mother, Man's monologue, in which he revisits his crush on the girl and expresses his long hidden feelings, is extraordinarily elongated and detailed. The girl who is the object of his nostalgic recollection, on the other hand, remains silent throughout, like an illusionary image. At the end of his monologue, Man laments:

She always appeared in my dreams to torment me whenever I was worried and couldn't set my mind free. I couldn't recall her name, I couldn't see her face clearly, I couldn't even get hold of her presence in any way, but she still kept on tormenting me. ${ }^{(33)}$

After which, Man turns to the Crowd who has been closely following him and asks:

Why do you keep following me? I need some peace and quiet, I need to be alone! $!^{(34)}$

This scene where Man recalls his puppy love can be seen as a representation of his memory, which is illusionary in nature but contains a direct reference to the previous scene of the Crowd learning to speak and killing Woman. With the scene "Learning to Speak" as the centre of the narrative, there is before it the performance of the fictionality of theatre and after it the depiction of an illusionary personal experience. In terms of dramatic structure, the entire episode can be understood as a piece of historical reality being framed by fictional narrative. As such, the meaning of the historical reality, namely, the incident that instantly reminds one of the Cultural Revolution experience, has to be appreciated within this fictional frame. Not only is this particular historical incident being framed to appear unreal, but the conventional belief that there is a true fact of history is also being re-evaluated.

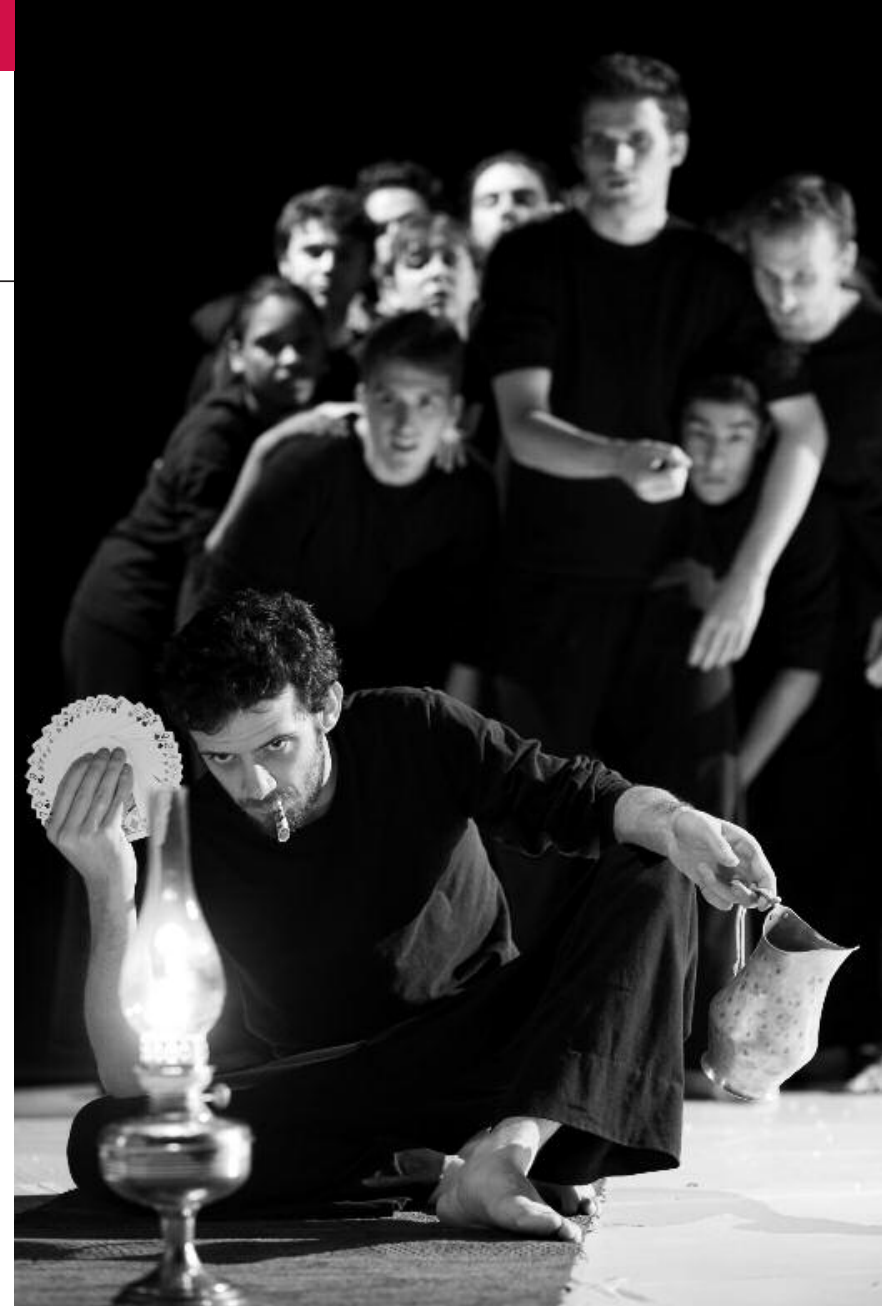

The scene that follows is "The Card Game." In this scene, a character named Card Player is seen hosting a game of cards as the banker. He first draws a card, which happens to be a two of spades - the smallest valued card one could possibly get. He then announces that the spade is the trump card and if a player picks a spade of any number higher than two, he/she will be the winner and will be rewarded with a drink of wine. If, however, the player does not pick a spade, he/she will be considered the loser and will have to stick a piece of paper on his/her face. Without exception, as the game goes on, everyone picks a card other than a spade and is obliged to stick a piece of paper on his/her face. The losers appear embarrassed at first but soon start to enjoy the game. All this while, Man is out of the game, watching the crowd coldly. When he is asked why he is not taking part, he replies:

Don't you understand? You're not really playing cards, he's playing a trick on you. You can't win. Your card, yours, and yours are all no trumps, including all the cards still in the deck. The only spade in the deck is in his hand! ${ }^{(35)}$
32. Gao Xingjian, The Other shore, p. 14.
33. Ibid., p. 16.
34. Ibid., p. 16.
35. Ibid., p. 20. 
At this instance, Card Player draws a card from the deck a no-trump card. He then asks around if it is a spade or not. The players at first hesitate to give a clear answer, but later sound certain that the card is a spade, especially after Card Player lures them with wine. Further instigated by Card Player, the crowd uses verbal and physical violence to pressure Man to agree with them. In the end, Man is forced to say that it's a spade.

This scene clearly serves to represent a situation in which truth and falsehood are mixed up or even reversed. What Card Player says shortly after this scene can be regarded as a deeply ironic comment on this situation:

You heard what they said, didn't you? Why did you lie, why did you insist that a spade is no trump? You're scared, aren't you? Have you ever tried eating rat meat? A bouncing baby rat, its hair not fully grown and its eyes unopened, the little creature still squeaking when you dip it in the sauce and put it in your mouth, ready for a bite? If you had, then you'd be brave enough to tell the truth. ${ }^{(36)}$

In his relatively detailed description of the process of rat eating, Card Player unequivocally puts across to the audience an impression of brutality and violence. By suggesting that the condition of telling the truth is the courage to swallow a living rat, the notion of truth in Card Player's narration is subverted. The intrinsic meaning of truth is thus transformed from the real to the fictional. As such, the incident represented in this scene, despite its realness in terms of a collective experience, has been performed not as reality but with a focus on its fictionality.

This particular scene of "The Card Game" has been framed, in a way similar to "Learning to Speak," with the exposition of dramatic fictionality. Immediately preceding it is the scene where Man meets his dead mother and the girl with whom he was secretly in love. Following it is a scene where Man appears as a character called Youth, telling the story of his encounter with three characters: Young Girl, Father, and Old Lady. This character Youth can be seen as a representation of Man in his younger years as well as a representation of his distant memory. All of these characters and the content of their dialogue display an illusionary and fictionalised trait. Although the scenes "Learning to Speak" and "The Card Game" are both framed by fictional narrative, the fundamental difference is that while the lat- ter is entirely framed by the personal memory and illusion of Man, the former is also framed by employing the form of theatrical suppositionality.

Although the details of collective violence narrated in both scenes do not directly refer to a historical occurrence, these scenes appear to be representations of certain aspects of the Cultural Revolution and thus metaphorical depictions of some "facts" of a historical event. While other scenes in The Other Shore are mainly personal journeys in non-collective, individualised situations, these two scenes recount the oppression of and violence against an individual by the collective. It should also be noted that these two scenes are significantly longer and more detailed than any other scenes in The Other Shore, which are primarily brief and episodic. The emotional impact of these two scenes on the audience is therefore predictably stronger and more lasting. If the audience comes to a performance of The Other Shore with prior knowledge of the historical incident, they will see a retelling of that history that may corroborate their existing perception. In this respect, watching the scenes may give the audience the experience of revisiting collective memory.

The Other Shore is not, however, a realistic depiction (if that is ever possible) of a historical incident. Although the historical incident may appear real in collective memory, it is not represented as historical reality in this play. The entire play has created a structural framework with multiple layers, with the incidents closest to reality encompassed in the inner-most circles of the narrative structure and hence requiring the audience to perceive these incidents through a perspective constructed by multiple frames of narrative. I would propose the following figure, which I have created in relation to my discussion of framing in an attempt to show how the multi-layered narrative in The Other Shore is structured:

In this structural framework, it is apparent that the two scenes earlier discussed in detail, namely "Learning to Speak" and "The Card Game," are located in the innermost circles of the framework, suggesting that these incidents, existing in the personal memory of the protagonist Man, are framed by the narrative of the dramatic characters. The circle one layer further out is dedicated to the exposition of the process through which actors take up the roles of the dramatic characters, thus revealing that these characters are indeed fictional and being performed. This is the middle layer of the framework. One layer further out-

36. Ibid., p. 21 
Figure 1. Structural Framework of The Other Shore

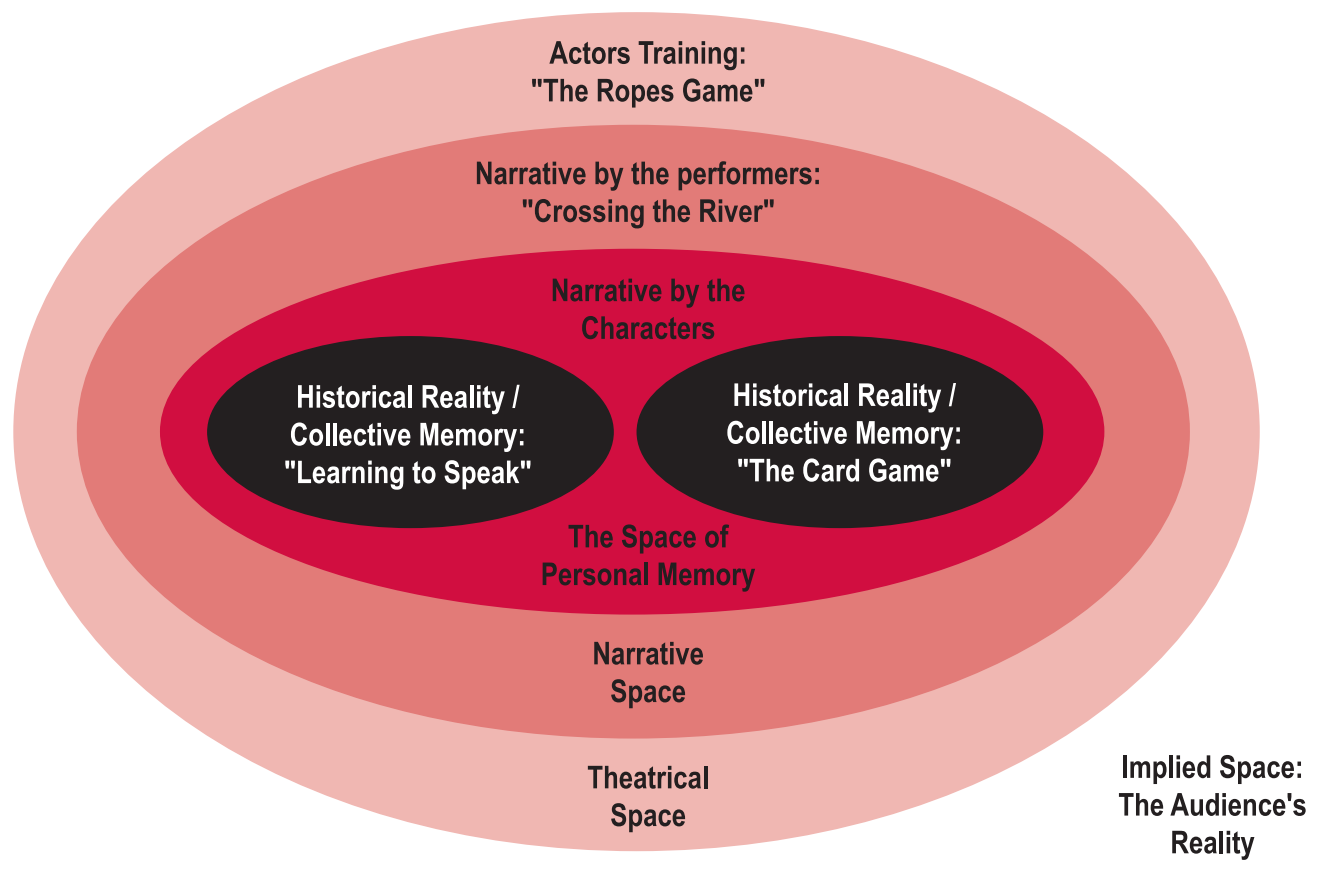

side is the layer corresponding to the beginning of The Other Shore, when the Actor playing with ropes appears in his capacity as an actor and shows the process of actor training. This part of the play takes place in the theatrical space in which the following narrative is to be carried out. This outermost layer of the framework is also the physical and real space in which the audience is watching the performance.

The three layers of structural framework in The Other Shore are constructed through the exposition of performance and narrative and hence the revelation of the fictionality of the framework. However, the play does not end at this third layer. At the end of the performance of The Other Shore, all performers appear to resume their identities as individuals in real life outside the theatre. All their utterances appear unrelated to what has just been performed:

\section{[...]}

This kitten is so cute.

I think I've seen you somewhere.

I have a sweet tooth, and I'm also a sucker for sour milk. $[\ldots]$

How are you going to get back?

It's so bad, what kind of stupid play is this anyway?

Are you doing anything tomorrow? Shall we have

dinner together? ${ }^{(37)}$

The function of these utterances - their content and the way they are expressed - is to transpose the narrative out of the dramatic context that has been constructed through the entire performance, and hence brings the audience away from the theatrical space, that is, to the space of reality outside the theatre. In so doing, the multi-layered structural framework of fictionality is eventually deconstructed by reference to reality. With this final twist comes an understanding of the complex ironic structure of The Other Shore: The play deconstructs the representation of historical reality with a fictional structure; at the end, the fictional structure is deconstructed by reference to reality. In a time when the Cultural Revolution is a largely taboo subject (and it still is now), Gao's theatrical representation provides the audience with an effective medium for remembering and reflecting on the

37. Ibid., p. 41. 
recent past. Although it is unfortunate that The Other Shore has not had a chance to be produced in China, a public staging of the play might provoke much harsher attacks than The Bus Stop.

\section{Conclusion: Frame as metaphor}

In The Other Shore, Gao Xingjian uses the Buddhist notion of the other shore as a metaphor for contemporary China, but the metaphor of the other shore in the play does not have the meaning of the original Buddhist notion. Looking at the structural framework and the representations within the framework, "China" as the other shore is represented in a vehemently ironic manner. This framework and its ironic connotations can be seen as a critique of China's reality through dramatic representation. Gao once soberly remarked, "When a person is suddenly divorced from his ancestral land, a distance is created that allows him to become more detached in writing about it." (38) By remaining in a state that is always in transition and hence unstable, a writer such as Gao creates for himself a consciousness of detachment that allows him to observe and understand China from a critical distance. On another occasion, Gao observes, "I feel it is best for a writer to stay at the periphery of society so as to remain sober and to be able to observe this society without being unwillingly drawn into the mechanism of the society." ${ }^{(39)}$ By distancing himself from the reality of China, first psychologically and then physically, Gao has gained the freedom to observe China with an alternative perspective through the (de)construction of a structural framework. 